\title{
INTRODUCTION
}

\section{The Biology, Ecology and Conservation of Elasmobranchs: Recent Advances and New Frontiers}

D. W. Sims ${ }^{1,2,3}$

${ }^{1}$ Marine Biological Association of the United Kingdom, The Laboratory, Citadel Hill, Plymouth PL1 2PB, UK

${ }^{2}$ Ocean and Earth Science, National Oceanography Centre Southampton, University of Southampton, Waterfront Campus, European Way, Southampton SO14 3ZH, UK

${ }^{3}$ Centre for Biological Sciences, Building 85, University of Southampton, Highfield Campus, Southampton SO17 $1 B J, U K$

Email:dws@mba.ac.uk

The elasmobranchs (sharks, skates and rays) are cartilaginous fishes that are important predatory and scavenging species within aquatic ecosystems, and as living resources to human societies globally in cultural, economic, health, biodiversity and conservation contexts. There are over 900 extant species, including the world's largest fish (the whale shark Rhincodon typus), that arose sometime during c. 400 million years of independent evolution, with the main living families having first appeared sometime between the Permian and Jurassic Periods ( 250-150 million years ago). Extant elasmobranchs possess an intriguing set of biological characteristics, including, for example, larger brains than other ectothermic vertebrates (Northcutt, 1977), slow growth and late age at maturity (Cailliet \& Goldman, 2004), internal fertilisation and female sperm storage (Metten, 1939; Feldheim et al., 2002), diverse reproductive modes including oviparity and viviparity (Dulvy \& Reynolds, 1997), relatively low fecundity, and social systems with dominance hierarchies and segregation by sex and age (Wearmouth \& Sims 2008; Mucientes et al., 2009).

In some respects the behavioural, ecological and life-history strategies of elasmobranchs share certain characteristics that are arguably more similar to mammals and birds than other fishes. These include, for example, sex-biased dispersal (Pardini et al., 2001) and long-distance return migrations from foraging habitat to breeding grounds (Lea et al., 2015a). These attributes in addition to other more unique features have also made elasmobranchs important model organisms for developmental, biomedical and evolutionary research (Oulion $e t$ al., 2011). Furthermore, elasmobranchs occupy a very broad range of habitats worldwide and have a key role in the functioning of ecosystems (Heithaus et al., 2008). Taken together this identifies elasmobranchs as an important group to study for advancing fundamental biological knowledge in key fields ranging from molecular genetics and genomics to physiology, and from behaviour to population and community ecology. However, lifehistory traits such as slow growth, late maturity and low fecundity make elasmobranchs less resilient to exploitation (Dulvy et al., 2014). Many sharks, skates and rays are highly valued worldwide by commercial fisheries, exploitation that has led to dramatic declines in the population levels of numerous species (Baum et al., 2003; Ferretti et al., 2010). There is particular concern that target and by-catch fisheries are depleting populations below sustainable levels where recovery may not be possible, or at best may be very slow, even if 
fishing pressure is removed (Field et al., 2009). An increasing number of elasmobranchs are being listed in the International Union for the Conservation of Nature (IUCN) Red List of threatened species, with some larger species of greater economic value now being listed on the Convention of International Trade in Endangered Species (CITES) (Dulvy et al., 2014).

The conservation of elasmobranch populations in the face of pressures such as the expansion of industrialised fisheries, the degradation or removal of habitats, and, for many species, little or no management, require novel solutions for sustainable exploitation. These concerns about elasmobranch populations and the need for science to inform conservation measures provided the backdrop to the Fisheries Society of the British Isles (FSBI) Annual Symposium on the "Biology, Ecology and Conservation of Elasmobranchs: Recent Advances and New Frontiers", that took place in Plymouth, U.K., on 27th - 31st July 2015. Our key aim was to explore how new scientific and technological approaches, such as biotelemetry, robotics, reproductive physiology and genomics for example, can contribute to improved conservation. This Special Issue of the Journal of Fish Biology arises from this Symposium.

The city of Plymouth in the south-west of England in the U.K. was an inspired choice of location for this FSBI Symposium because it has a long history of pioneering discoveries in elasmobranch research. For example, research undertaken at the Laboratory of the Marine Biological Association of the U.K. on Plymouth Hoe contributed important advances, including for instance the first scientific descriptions of sex and age segregation behaviour in elasmobranchs (Ford, 1921), the thermal sensory capabilities of the ampullae of Lorenzini revealed with the then new technique of electrophysiology (Sand, 1938), and seminal work determining the function of the two myotomal muscle fibre types in sharks (Bone, 1966).

The FSBI Symposium welcomed 170 scientists from 34 countries (Figure 1), with 85 speakers, 39 of whom were women, and an impressive range of ages represented, from undergraduates to emeritus professors. It was evident from this engaging symposium that elasmobranch biology and ecology is a diverse and vibrant field of science. The topics covered spanned levels of biological organisation from molecules and cells to systems biology, and from individuals and populations up to communities and ecosystems. Over five days the scientific presentations provided new insights into elasmobranch movements, behaviour and habitat use; genomics and evolution; population structure, distribution and phylogeography; population ecology, fisheries biology, and management; and conservation.

The 13 papers presented in this Special Issue of the Journal of Fish Biology span the scientific topics presented and discussed at the Symposium. A major focus of the meeting was to explore how new technologies are being developed to push back the boundaries of existing knowledge. The paper by Gregory Skomal, a keynote speaker at the symposium, and his colleagues (this issue, page XX), , illustrates that focus well by describing a new autonomous vehicle capable of tracking the fine-scale movements of foraging white sharks (Carcharodon carcharias), complete with video to record what individuals were actually doing in shallow surf zones where they overlap with humans. The field of animal-attached telemetry technology is also burgeoning, especially with respect to how it can inform conservation strategies. The paper by Lea et al. (page XX) shows how pop-off satellite-linked archival transmitters revealed the $2,000 \mathrm{~km}$ return migration of a female bull shark (Carcharhinus leucas) from the Seychelles to Madagascar to give birth, thus identifying unknown nursery habitats and philopatry in this species. Similarly, Guttridge et al. (page XX) used satellite transmitters and 
acoustic telemetry to locate key habitat of the critically endangered smalltooth sawfish (Pristis pectinata) in the Bahamas, results which emphasize the urgent need for protection and management of this population. Importantly for endangered species, Bullock et al. (page XX) remind us that using new technologies to track the movements, behaviour and energetics of elasmobranchs requires evaluation of the potential impacts of these electronic devices on normal activity and behaviour, since tags can remain attached to the animal for many years.

How shark populations are structured in space and time was a question thoroughly addressed during the Symposium and it was evident that several approaches to this problem in addition to telemetry are already bearing fruit. The paper by Bruce and Bradford (page XX) used detailed time-series of white shark occurrence off South Australia to identify that sex-specific foraging strategies may play an important role in structuring movement patterns, while Gledhill et al. (page XX) used molecular genetic methods to reveal the population structuring of blacktip sharks (Carcharhinus limbatus) in the Bahamas and U.S. east coast waters.

Perhaps one of the most commonly asked questions from the public about elasmobranchs is how long do they live for? A paper by the FSBI Symposium's Jack Jones Memorial Lecturer, Gregor Cailliet (page XX), provides an authoritative review on the subject of age validation studies in elasmobranchs and spells out what the complex answers mean for fisheries management. In addition to lifespans, the growth rates and reproductive biology of elasmobranchs are also poorly known for the majority of species. The paper by Dureuil and Worm (page XX) utilises tagging data from the north-east Atlantic to estimate growth in the tope or school shark Galeorhinus galeus, whereas the papers by McCully-Phillips and Ellis (page XX) and Romero-Caicedo and Carrera-Fernández (page $\mathbf{X X}$ ), respectively, reveal hitherto unknown details about the reproductive characteristics of the starry smoothhound (Mustelus asterias) in the north-east Atlantic and the whitesnout guitarfish (Rhinobatos leucorhynchus) in the Pacific Ocean off Ecuador. Studies such as these are central to understanding a population's fecundity, growth and longevity, and thus can be used to estimate how susceptible elasmobranch species are likely to be to the effects of overfishing.

The role of fishing exploitation on elasmobranch populations and the future for their conservation was also a key theme of the Symposium. It was evident that to identify accurately the impacts of fishing it was also necessary to know about inter-annual variability in the presence of elasmobranchs due to other factors, a point well illustrated by the paper by Winter et al. (page XX) on the skate assemblage of the Patagonian shelf in the South Atlantic. Deep-water elasmobranchs are known to have slow growth and low fecundity and are thought to be particularly vulnerable to fisheries. The paper by Neat et al. (page XX) on the diversity, distribution and status of deep-water elasmobranchs in the Rockall Trough, north-east Atlantic concludes, importantly, that recovery from past exploitation was not evident several years after fishing was banned in this area. This provides a clear message that even when protection is in place for elasmobranchs it may take many years for populations to recover.

The Special Issue's final paper is a review co-authored by a Symposium keynote speaker, Julia Baum, who with G. Osgood reviews the ecology of reef sharks and how this undertanding can be used to inform conservation (Osgood and Baum, page XX). As these authors recognise, sharks are important members of coral reef communities, however they also point out that reef shark conservation status remains uncertain in many cases. 
For example, nine out of 29 reef shark species are designated as Data Deficient on the IUCN Red List, with three-quarters of reef sharks having unknown population trends. A knowledge gap of this size for a group of species that are so recognisable is surprising, but, fortunately, Osgood and Baum show that reef shark research is building up to bridge this gap.

Many elasmobranch populations are in decline, ranges have contracted for some and there are no regulations to control fishing for many species. But the global community of elasmobranch researchers and conservationists is growing fast, and they are working together to influence policy more effectively than ever before. And the application of technology is revolutionising the way we can view shark movements, map whole populations, and use forensics to identify species caught illegally. The future may be looking brighter for overexploited elasmobranch populations. In this context the review by Osgood and Baum exemplifies the FSBI Symposium very well, synthesising as it does information from diverse fields of study, such as population demography, life history, trophic ecology, genetics, habitat use and movement studies, then using this knowledge to help advance elasmobranch conservation. This is a vital and particularly timely aim for elasmobranch researchers and one that I feel the FSBI Symposium has contributed to, and which I hope is captured in the pages of this Special Issue.

\section{Acknowledgements}

I give my sincere thanks to the Fisheries Society of the British Isles for making the symposium possible, the FSBI President Ian Winfield for his guidance, my colleagues on the Symposium Scientific Advisory (G. Skomal, J. Semmens, N. Dulvy, J. Metcalfe) and Local Organizing Committees (A. Hood, S. Simpson, S. Banham, D. Gibson, N. Pade, V. Wearmouth) for their tireless work before, during and after the meeting, to our sponsors for their generosity, and to J. Ellis and J. Craig and H. Craig of the Journal of Fish Biology for their great work on the Special Issue. Finally, thanks to the Marine Biological Association for giving me the freedom to organise FSBI 2015 (see the Sympsoium presentations on Twitter \#FSBI2015).

\section{References}

Baum. J.K. et al. (2003) Collapse and conservation of shark populations in the northwest Atlantic. Science 299, 389-392.

Bone, Q. (1966) On the function of the two types of myotomal muscle fibre in elasmobranch fish. Journal of the Marine Biological Association of the UK 46, 321-349.

Bullock, R.W., Guttridge, T.L., Cowx, I.G., Elliott, M. \& Gruber, S.H. (2015) The behaviour and recovery of juvenile lemon sharks Negaprion brevirostris in response to external accelerometer tag attachment. Journal of Fish Biology, this issue.

Bruce, B. \& Bradford, R. (2015) Segregation or aggregation? Sex-specific patterns in the seasonal occurrence of white sharks Carcharodon carcharias at the Neptune Islands, South Australia. Journal of Fish Biology, this issue.

Cailliet, G.M. (2015) Perspectives on elasmobranch life history studies: a focus on age validation and relevance to fishery management. Journal of Fish Biology, this issue.

Cailliet, G.M., Goldman, K.J. (2004) Age determination and validation in chondrichthyan fishes. In Biology of Sharks and their Relatives (eds, J.C. Carrier, J.A. Musick, M.R. Heithaus), p. 399-447, CRC Press, Boca Raton, U.S.A.

Dulvy, N. K. \& Reynolds, J. D. (1997). Evolutionary transitions among egg-laying, livebearing and maternal inputs in sharks and rays. Proceedings of the Royal Society of London B 264, 1309-1315.

Dulvy, N.K. et al. (2014) Extinction risk and conservation of the world's sharks and rays. eLife 3:e00590.

Dureuil, M. \& Worm, B. (2015) Estimating growth from tagging data: an application to north-east Atlantic tope shark Galeorhinus galeus. Journal of Fish Biology, this issue.

Feldheim, K. A., Gruber, S. H. \& Ashley, M. V. (2002). The breeding biology of lemon sharks at a tropical nursery lagoon. Proceedings of the Royal Society of London B 269, 1655-1661. 
Ferretti, F., Worm, B., Britten, G.L., Heithaus, M.R. \& Lotze, H.K. (2010) Patterns and ecosystem consequences of shark declines in the ocean. Ecology Letters 13, 1055-1071.

Field, I.C., Meekan, M.G., Buckworth, R.C. \& Bradshaw, C.J.A. (2009) Susceptibility of sharks, rays and chimaeras to global extinction. Advances in Marine Biology 56, 275-363.

Ford, E. (1921). A contribution to our knowledge of the life-history of the dogfishes landed at Plymouth. Journal of the Marine Biological Association of the UK 12, 468-505.

Gledhill, K.S., Kessel, S.T., Guttridge, T.L, Hansell, A.C., Bester-van der Merwe, A.E., Feldheim, K.A., Gruber, S.H. \& Chapman, D.D (2015) Genetic structure. population demography and seasonal occurrence of blacktip sharks Carcharhinus limbatus in Bimini, the Bahamas. Journal of Fish Biology, this issue.

Guttridge T.L., Gulak S.J.B., Franks B.R., Carlson J.K. , Gruber S.H., Gledhill K.S., Bond M.E., Johnson G. \& Grubbs R.D. (2015) Occurrence and habitat use of the critically endangered smalltooth sawfish Pristis pectinata in the Bahamas. Journal of Fish Biology, this issue.

Heithaus, M.R., Frid, A., Wirsing, A. \& Worm, B. (2008) Predicting ecological consequences of marine top predator declines. Trends in Ecology and Evolution 23:202-210.

Lea, J.S.E., Wetherbee, B.M., Queiroz, N., Burney, N., Aming, C., Sousa, L.L., Mucientes, G.R., Humphries, N.E., Harvey, G.M., Sims, D.W. \& Shivji, M.S. (2015) Repeated, long-distance migrations by a philopatric predator targeting highly contrasting ecosystems. Scientific Reports 5, 11202. DOI:10.1038/srep11202.

Lea, J.S.E., Humphries, N.E., Clarke, C.R. \& Sims, D.W. (2015b) To Madagascar and back: long-distance, return migration across open ocean by a pregnant female bull shark Carcharhinus leucas. Journal of Fish Biology, this issue.

McCully Phillips, S.R. \& Ellis, J.R. (2015) Reproductive characteristics and life-history relationships of starry smooth-hound Mustelus asterias in British waters. Journal of Fish Biology, this issue.

Metten, H. (1939). Reproduction of the dogfish. Nature 143, 121-122.

Mucientes, G.R., Queiroz, N., Sousa, L.L., Tarroso, P. \& Sims, D.W. (2009) Sexual segregation of pelagic sharks and the potential threat from fisheries. Biology Letters 5, 156-159.

Neat, F.C., Burns, F., Jones, E. \& Blasdale, T. (2015) The diversity, distribution and status of deep-water elasmobranchs in the Rockall Trough, north-east Atlantic Ocean. Journal of Fish Biology, this issue.

Northcutt, R. G. (1977). Elasmobranch central nervous system organization and its possible evolutionary significance. American Zoologist $17,411-429$

Oulion, S., Borday-Birraux, V., Debiais-Thibaud, M., Mazan, S., Laurenti, P. \& Casane, D. (2011) Evolution of repeated structures along the body axis of jawed vertebrates, insights from the Scyliorhinus canicula Hox code. Evolution and Development 13, 247-259.

Osgood. G.J. \& Baum, J.K. (2015) Reef sharks: recent advances in ecological understanding to inform conservation. Journal of Fish Biology, this issue.

Pardini, A.T., Jones, C. S., Noble, L. R., Malcolm, H., Bruce, B. D., Stevens, J. D., Cliff, G., Scholl, M. C., Francis, M., Duffy, C. A. J., Kreiser, B. \& Martin, A. P. (2001). Sex-biased dispersal in great white sharks. Nature 412, 139-140.

Romero- Caicedo, A.F. \& Carrera-Fernández, M. (2015) Reproduction of the whitesnout guitarfish Rhinobatos leucorhynchus in the Ecuadorian Pacific Ocean. Journal of Fish Biology, this issue.

Sand, A. (1938) The function of the ampullae of Lorenzini, with some observations on the effect of temperature on sensory rhythms Proceedings of the Royal Society of London B 125, 524-553.

Skomal, G., Hoyos-Padilla, H.M., Kukulya, A. \& Stokey, R. (2015) Subsurface observations of white shark Carcharodon carcharias predatory behaviour using an autonomous underwater vehicle. Journal of Fish Biology, this issue.

Wearmouth, V.J. \& Sims, D.W. (2008) Sexual segregation in marine fish, reptiles, birds and mammals: Behaviour patterns, mechanisms and conservation implications. Advances in Marine Biology 54, 107-170.

Winter, A., Pompert, J., Arkhipkin, A. \& Brewin, P.E. (2015) Inter-annual variability in the skate assemblage on the South Patagonian shelf and slope. Journal of Fish Biology, this issue. 
Published in Journal of Fish Biology 87, 1265-1270 (2015)

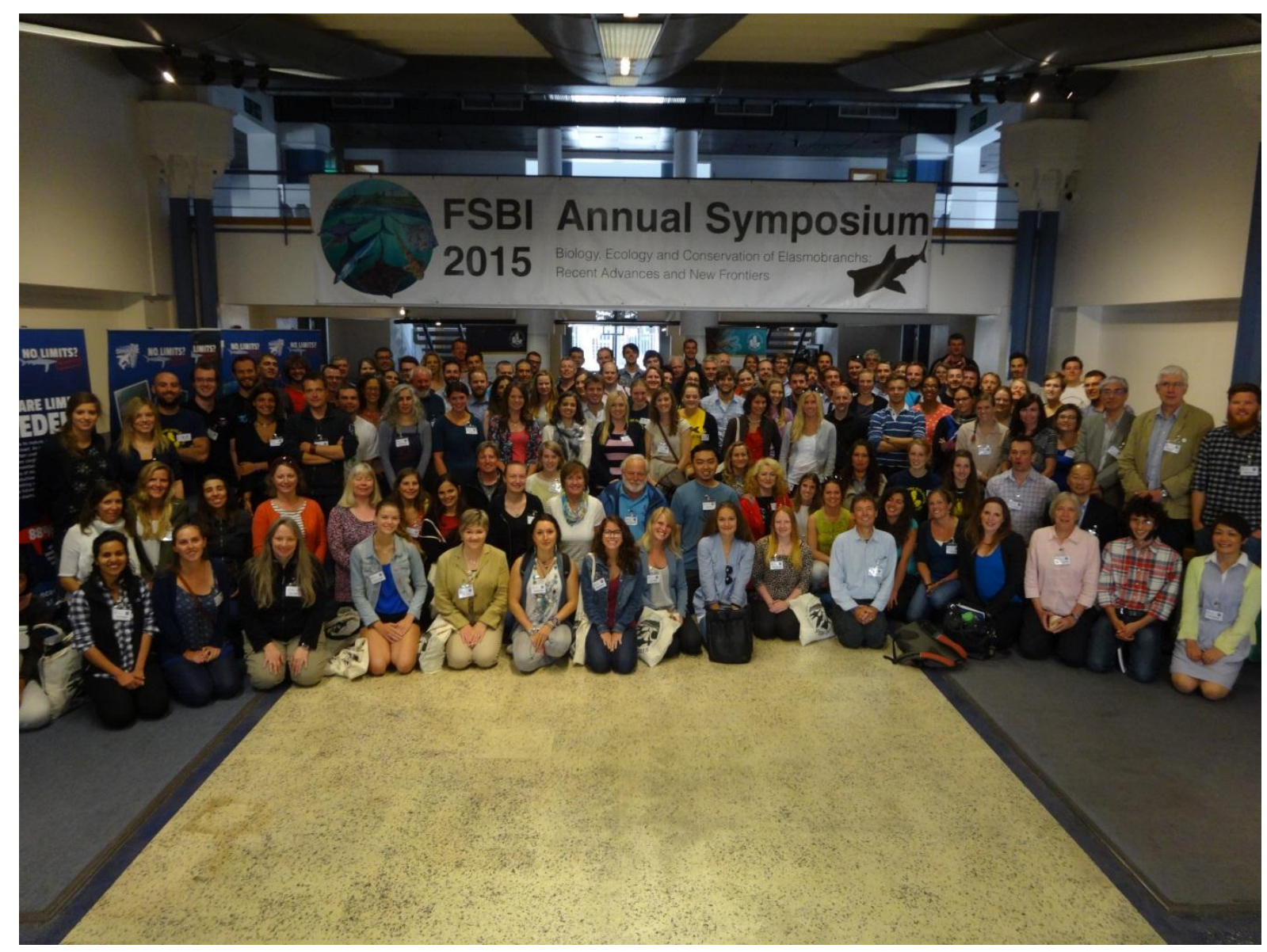

